\title{
INVESTIGATION OF HOLE PROFILES IN DEEP MICRO-HOLE DRILLING OF AISI 420 STAINLESS STEEL USING POWDER-MIXED DIELECTRIC FLUIDS
}

\author{
PREISKAVA PROFILOV LUKNJE PRI GLOBOKEM VRTANJU \\ MIKRO LUKNJE V AISI 420 NERJAVNEM JEKLU S POMOČJO \\ DIELEKTRIČNE TEKOČINE S PRIMEŠANIM PRAHOM
}

\author{
Volkan Yılmaz \\ Gazi University, Faculty of Technology, Manufacturing Engineering, Ankara, Turkey \\ volkan@gazi.edu.tr \\ Prejem rokopisa - received: 2015-05-18; sprejem za objavo - accepted for publication: 2015-07-13
}

doi:10.17222/mit.2015.100

\begin{abstract}
A series of experiments were carried out to drill deep micro-holes, using Electrical Discharge Machining (EDM) with different concentrations of carbon powder/dielectric fluid mixture into, and varying machining parameters such as elecrode rotation speed and dielectric fluid spray pressure. Four dielectric fluid concentrations, three electrode rotation speeds, and three dielectric fluid spray pressure settings were tested; the resulting holes were investigated with respect to their average radial overcut and surface roughness $\left(R_{\mathrm{a}}\right)$ values. Study results indicate that as carbon powder concentrations, dielectric fluid spray pressure and electrode rotation speeds are increased, $A R O$ values increased while $R_{\mathrm{a}}$ values are observed to decrease. It was determined that improvements in $R_{\mathrm{a}}$ and $A R O$ values may be attained by the right configuration of machining parameters and the selection of the appropriate mixtures of carbon powder with dielectric fluid.
\end{abstract}

Keywords: AISI 420 stainless steel, deep micro-hole drilling, electro discharge machining, hole profile, surface roughness

Izvedena je bila vrsta eksperimentov vrtanja globokih mikroizvrtin s pomočjo EDM in različne koncentracije prahu ogljika, primešanega dielektrični tekočini pri spreminjanju parametrov obdelave, vključno s hitrostjo vrtenja elektrode in tlaka curka dielektrične tekočine. Preizkušene so bile štiri koncentracije dielektrične tekočine, tri hitrosti vrtenja elektrode in trije različni tlaki curka dielektrične raztopine; nastale luknje so bile preiskovane glede na povprečni radij preseka in vrednosti hrapavosti površine $\left(R_{\mathrm{a}}\right)$. Rezultati kažejo, da naraščanje koncentracije prahu ogljika, tlak curka tekočine in hitrost rotacije elektrode povečuje vrednosti $A R O$, medtem ko se vrednost $R_{\text {a }}$ zmanjšuje. Bilo je ugotovljeno, da je mogoče izbolšanje vrednosti $R_{\text {a }}$ in $A R O$ mogoče doseči s konfiguracijo parametrov obdelave in z izbiro primerne količine prahu ogljika, ki je primešan dielektrični tekočini.

Ključne besede: AISI 420 nerjavno jeklo, vrtanje globokih mikroizvrtin, obdelava z elektroerozijo, profil luknje, hrapavost površine

\section{INTRODUCTION}

In recent years, the use of Electrical Discharge Machining (EDM) for drilling small diameter holes in very hard materials has gathered momentum, as the materials used in newly developed systems exhibit advanced mechanical properties and conventional drilling methods fall short in such materials. In EDM, there is no direct contact between the drilling tool and the workpiece, a significant benefit which eliminates the problems associated with physical contact. ${ }^{1-8}$ The EDM method is based on principles of thermal and electrical conductivity whereby small regions on the workpiece surface are removed by melting and vaporization. EDM systems allow the drilling of specific diameter holes provided that the material is electrically conductive. ${ }^{9}$ The EDM method is used for applications such as machine assembly points, fuel injection spray nozzles and aircraft engine cooling holes. EDM hole drilling has found applications at both the macroscale and microscale, with good surface quality and acceptable tapering. ${ }^{10}$
Due to electrode wear and lateral erosion, EDM holes exhibit some, albeit a small, amount of tapering. This is a complication for the EDM industry to overcome. Research is being conducted into reducing the tapering, and disparities between hole entry and exit diameters are reported to have been reduced to acceptable levels. ${ }^{11}$ Additionally, it has been reported that the problem may be surmounted with the use of coating on the tool electrode. ${ }^{12,13}$ The parameters used for EDM hole drilling have a significant effect on hole tapering and surface roughness. ${ }^{14-16}$ Rotation of the electrode has enhanced hole drilling performance in EDM operations. ${ }^{17,18}$ The type of dielectric fluid and the manner in which it is applied have improved the process. ${ }^{19,20}$ In addition to the tapering of the holes in EDM hole drilling, the surface roughness of hole walls is also of importance. It has been reported that the electrode plunge action is facilitated by rotational movement, and that surface roughness is simultabneously improved. ${ }^{21}$ Various types of electrodes are used in EDM and by changing their polarization, the surface roughness of holes have been reported to be 
reduced..$^{22}$ It is also reported that ancillary equipment can achieve significant enhancements in surface roughness. ${ }^{23}$ In EDM hole drilling in tandem with grinding, improved surface roughness results have been achieved. ${ }^{24}$ Additionally, system hybridization has been implemented resulting in the process duration being decreased while quality has been enhanced. ${ }^{25}$

One factor affecting machining performance in EDM is the conductive powder mixed with the dielectric fluid. Thanks to the conducting particulate, EDM processing, including hole drilling, is improved. The presence of conductive particulates not only improves hole drilling performance, but also has positive effects on hole tapering and hole surface roughness. ${ }^{26-28}$ However, despite the existence of several studies concerning hole drilling using powder-mixed dielectric fluids, the benefits and drawbacks of the method have yet to be established.

This study focuses on carbon $(\mathrm{C})$ powder mixed with the dielectric fluid, as well as two specific EDM parameters, and attempts to determine their effect on hole profile and surface roughness. In a survey of the literature, no studies have been identified targeting hole profile and surface roughness properties of the EDM micro-hole drilling method using either classical or powder-mixed EDM in AISI 420 material; this study attempts to fill the gap.

\section{EXPERIMENTAL SETUP}

For machining, a Furkan brand EEI M50A model EDM machine was used. A custom attachment was

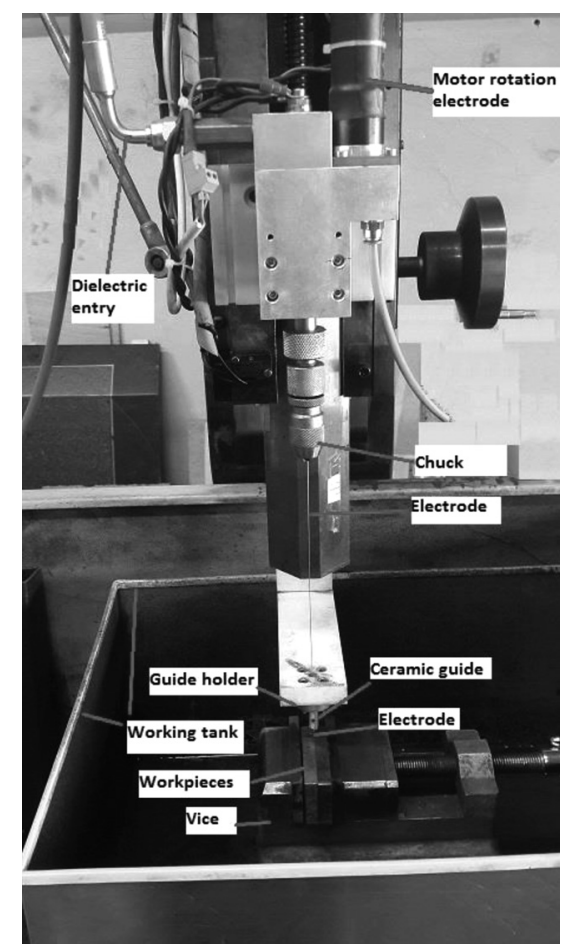

Figure 1: Custom attachment to enable electrode rotation Slika 1: Prilagoditev, ki omogoča vrtenje elektrode

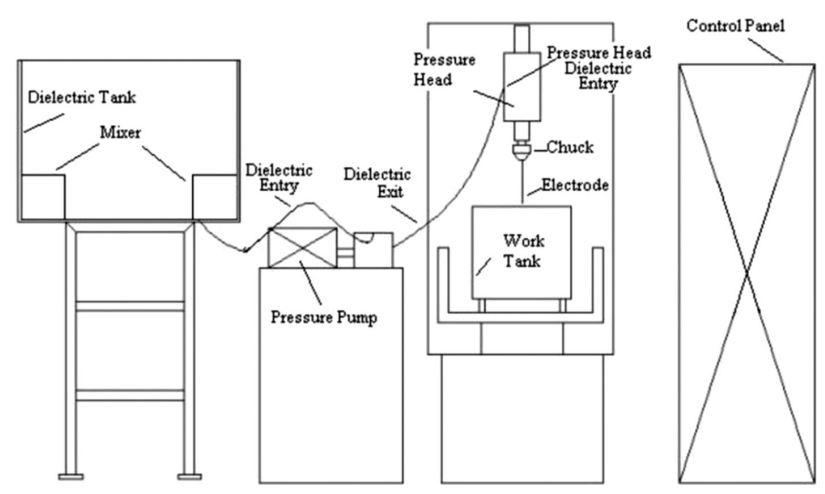

Figure 2: Experiment set-up Slika 2: Eksperimentalni sestav

mounted on the EDM tool head to allow for the rotation of the electrode at various $\mathrm{min}^{-1}$ (revolutions per minute) speeds and to provide for the dielectric fluid to be delivered through the tool, at the required pressure, to the area to be machined on the workpiece. The attachment is shown in Figure 1; the EDM machine and the testing set-up are shown in Figure 2.

Single-hole brass pipe with diameter of $0.5 \mathrm{~mm}$ was used as tool electrode; AISI 420 stainless steel, commonly utilized in the manufacturing industry as hot work tool steel and also used for turbine blade construction, was selected as the workpiece; distilled water in pure form as well as distilled water mixed with carbon powder at three concentrations $(2 \mathrm{~g} / \mathrm{L}, 4 \mathrm{~g} / \mathrm{L}$ and $8 \mathrm{~g} / \mathrm{L})$ were used as dielectric fluids. The chemical composition of AISI 420 is presented in Table $\mathbf{1}$ and the workpiece, electrode and carbon powder physical characteristics in Table 2. Table 3 shows the machining parameters used in the testing.

Table 1: Chemical composition of the AISI 420 material in mass fractions, $(w / \%)$

Tabela 1: Kemijska sestava materiala AISI 420, v masnih deležih $(w / \%)$

\begin{tabular}{|c|c|c|c|c|c|}
\hline $\mathrm{C}$ & $\mathrm{Mn}$ & $\mathrm{Si}$ & $\mathrm{P}$ & $\mathrm{S}$ & $\mathrm{Cr}$ \\
\hline 0.1 & 1.00 & 1.00 & 0.04 & 0.030 & 12.0 \\
\hline
\end{tabular}

The average radial overcut value is determined by taking the sum of the individual measurements of the hole diameter along the depth of the hole (Figure 3), averaging the sum, subtracting the result from the tool electrode diameter $d_{\mathrm{e}}$, and dividing by 2 :

$\operatorname{ARO}(\mu \mathrm{m})=\frac{\left[\left(\frac{d 1+d 2+d 3+d 4+d 5+d 6+d 7}{7}\right)-d_{\mathrm{e}}\right]}{2}$

The surface roughness values were measured using a Mitutoyo Surftest SJ-210. The values were determined through an arithmetical averaging of several readings for each hole. 
Table 2: Workpiece, electrode and carbon powder physical characteristics

Tabela 2: Fizikalne značilnosti obdelovanca, elektrode in prahu ogljika

\begin{tabular}{|c|c|c|c|c|c|}
\hline Material & Density $\left(\mathrm{gr} / \mathrm{cm}^{3}\right)$ & $\begin{array}{c}\text { Specific heat } \\
\text { capacity }\end{array}$ & Electrical resistivity & $\begin{array}{c}\text { Thermal conduc- } \\
\text { tivity }(\mathrm{W} / \mathrm{m} \mathrm{K})\end{array}$ & Melting point $\left({ }^{\circ} \mathrm{C}\right)$ \\
\hline AISI 420 & 7.75 & $460(\mathrm{~J} / \mathrm{kg} \mathrm{K})$ & $55(\mu \Omega-\mathrm{cm})$ & 24.9 & 1450 \\
\hline Brass & 8.25 & $0.380\left(\mathrm{~J} / \mathrm{g}{ }^{\circ} \mathrm{C}\right)$ & $6.39(\mu \Omega-\mathrm{cm})$ & 159 & 900 \\
\hline C powder & 2.25 & - & $12.2(\mu \Omega-\mathrm{m})$ & 100 & 3527 \\
\hline
\end{tabular}

Table 3: Machining parameters

Tabela 3: Obdelovalni parametri

\begin{tabular}{|l|l|}
\hline Discharge current $(I)(\mathrm{A})$ & 6 \\
\hline Pulse duration $($ On-time $)(\mu \mathrm{s})$ & 200 \\
\hline Pulse interval $($ Off-time $)(\mu \mathrm{s})$ & 100 \\
\hline Electrode rotational speed $\left(\mathrm{min}^{-1}\right)$ & $100,200,400$ \\
\hline Dielectric spray pressure $(\mathrm{bar})$ & $20,40,80$ \\
\hline Polarity & Electrode $(+)$, Workpiece $(-)$ \\
\hline Dielectric Fluid & Pure distilled water, pure distilled water with carbon powder \\
\hline Workpiece & AISI 420 \\
\hline Electrode & Brass \\
\hline Processing depth $(\mathrm{mm})$ & 20 \\
\hline Electrode diameter $(\mathrm{mm})$ & 0.5 \\
\hline
\end{tabular}

\section{RESULTS AND DISCUSSION}

Using EDM, micro-holes with a diameter of $0.5 \mathrm{~mm}$ and depth of $20 \mathrm{~mm}$ were drilled into AISI 420 steel workpiece using four dielectric fluid concentrations (pure distilled water, and distilled water with carbon powder concentrations of $2 \mathrm{~g} / \mathrm{L}, 4 \mathrm{~g} / \mathrm{L}$, and $8 \mathrm{~g} / \mathrm{L}$ ), three electrode rotation speeds $\left(100 \mathrm{~min}^{-1}, 200 \mathrm{~min}^{-1}\right.$ and $\left.400 \mathrm{~min}^{-1}\right)$, three spray pressure settings for the dielectric fluid (20 bar, 40 bar, and 80 bar), with constant discharge current (6 A), pulse duration $(200 \mu \mathrm{s})$ and pulse interval $(100 \mu \mathrm{s})$. The effects of the machining parameters on the $A R O$ values for hole profile and surface roughness have been investigated. Sample drillings are presented in Figure 4.

The study was designed to test the dielectric fluid mixes against dielectric fluid pressure and electrode rotation speed. Test numbers in the following description are described in Table 3: Four groups of dielectric fluid

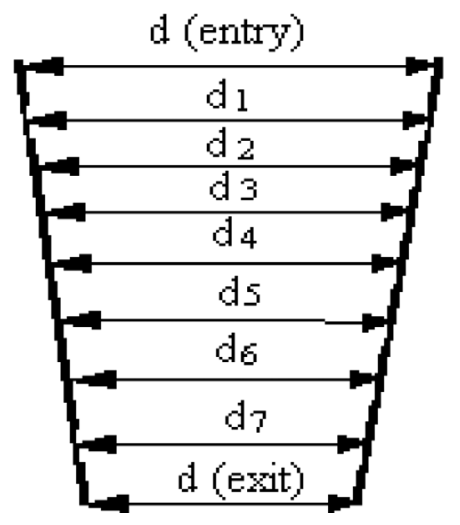

Figure 3: Measurements along hole profile Slika 3: Meritve vzdolž profila izvrtine were used for testing (Di-0: pure distilled water with no powder mix, Di-1: distilled water with $2 \mathrm{~g} / \mathrm{L}$ carbon powder mix, Di-2: with $4 \mathrm{~g} / \mathrm{L}$ mix, Di-3: with $8 \mathrm{~g} / \mathrm{L}$ mix). Three separate powder mixes were subjected to three groups of tests (A, B, and C), with three tests in each test group $(1,2$, and 3$)$. For the three test groups, the pressure setting of the dielectric fluid was varied (A: 20 bar, B: 40 bar and C: 80 bar). For each individual test within a test group, the electrode rotation speed was varied (1: $100 \mathrm{~min}^{-1}, 2: 200 \mathrm{~min}^{-1}$ and 3: $\left.400 \mathrm{~min}^{-1}\right)$. For each individual test, the average radial overcut $(A R O)$

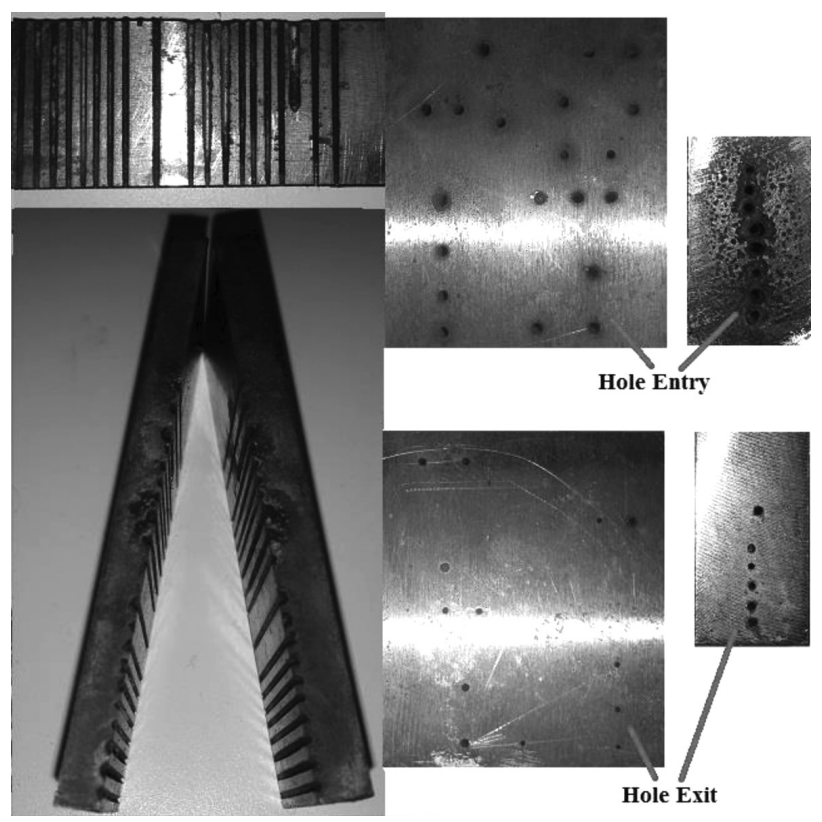

Figure 4: Sample drillings Slika 4: Vzorčne izvrtine 
Table 4: Test organization and results

Tabela 4: Zasnova preizkusov in rezultati

\begin{tabular}{|c|c|c|c|c|c|c|c|c|c|c|}
\hline \multirow[b]{2}{*}{$\begin{array}{l}\text { Test } \\
\text { group }\end{array}$} & \multirow[b]{2}{*}{\begin{tabular}{|} 
Dielectric \\
fluid spray \\
pressure \\
(bar)
\end{tabular}} & \multirow[b]{2}{*}{$\begin{array}{l}\text { Electrode } \\
\text { rotation } \\
\left(\min ^{-1}\right)\end{array}$} & \multicolumn{2}{|c|}{$\begin{array}{l}\text { Di-0 } \\
\text { Pure distilled water } \\
\text { (no powder mix) }\end{array}$} & \multicolumn{2}{|c|}{$\begin{array}{c}\text { Di-1 } \\
\text { Distilled water with } \\
\text { carbon } \\
(2 \mathrm{~g} / \mathrm{L})\end{array}$} & \multicolumn{2}{|c|}{$\begin{array}{l}\text { Di-2 } \\
\text { Distilled water with } \\
\text { carbon } \\
(4 \mathrm{~g} / \mathrm{L})\end{array}$} & \multicolumn{2}{|c|}{$\begin{array}{c}\text { Di-3 } \\
\text { Distilled water with } \\
\text { carbon } \\
(8 \mathrm{~g} / \mathrm{L})\end{array}$} \\
\hline & & & $\begin{array}{l}\text { Average } \\
\text { radial } \\
\text { overcut } \\
(\mu \mathrm{m})\end{array}$ & $\begin{array}{l}\text { Surface } \\
\text { roughness } \\
R_{\mathrm{a}}(\mu \mathrm{m})\end{array}$ & $\begin{array}{l}\text { Average } \\
\text { radial } \\
\text { overcut } \\
(\mu \mathrm{m})\end{array}$ & $\begin{array}{l}\text { Surface } \\
\text { roughness } \\
R_{\mathrm{a}}(\mu \mathrm{m})\end{array}$ & $\begin{array}{l}\text { Average } \\
\text { radial } \\
\text { overcut } \\
(\mu \mathrm{m})\end{array}$ & $\begin{array}{c}\text { Surface } \\
\text { roughness } \\
R_{\mathrm{a}}(\mu \mathrm{m})\end{array}$ & $\begin{array}{l}\text { Average } \\
\text { radial } \\
\text { overcut } \\
(\mu \mathrm{m})\end{array}$ & $\begin{array}{l}\text { Surface } \\
\text { roughness } \\
R_{\mathrm{a}}(\mu \mathrm{m})\end{array}$ \\
\hline A-1 & \multirow{3}{*}{20} & 100 & 42 & 3.25 & 62 & 2.46 & 77 & 2.14 & 81 & 1.92 \\
\hline A-2 & & 200 & 48 & 2.98 & 65 & 2.24 & 79 & 2.06 & 88 & 1.87 \\
\hline A-3 & & 400 & 51 & 2.79 & 77 & 2.06 & 84 & 1.92 & 93 & 1.75 \\
\hline B-1 & \multirow{3}{*}{40} & 100 & 53 & 3.04 & 71 & 2.35 & 82 & 2.05 & 92 & 1.85 \\
\hline B-2 & & 200 & 59 & 2.82 & 78 & 2.18 & 86 & 1.95 & 98 & 1.82 \\
\hline B-3 & & 400 & 64 & 2.70 & 83 & 2.02 & 94 & 1.85 & 104 & 1.63 \\
\hline C-1 & \multirow{3}{*}{80} & 100 & 65 & 2.66 & 86 & 2.26 & 91 & 1.92 & 101 & 1.81 \\
\hline C-2 & & 200 & 72 & 2.62 & 88 & 2.11 & 94 & 1.88 & 105 & 1.74 \\
\hline $\mathrm{C}-3$ & & 400 & 76 & 2.51 & 94 & 1.96 & 102 & 1.73 & 112 & 1.68 \\
\hline
\end{tabular}

and surface roughness $\left(R_{\mathrm{a}}\right)$ values were recorded. Results of the tests are presented in Table 4.

\subsection{Examination of the results obtained for surface roughness $\left(R_{\mathrm{a}}\right)$}

Variations in $R_{a}$ values in response to machining parameters and the concentration of carbon powder used in the dielectric fluid are presented graphically in Figures 5 and 6. A fundamental goal of EDM processing in manufacturing is to achieve low surface roughness $\left(R_{\mathrm{a}}\right)$ values. While having a direct relationship with the machining parameters, $R_{\mathrm{a}}$ values are also influenced by factors such as the workpiece itself, the type of dielectric fluid used, the dielectric application method and the type of electrode used. , $7,29,30,31^{2}$

Figures 5 and $\mathbf{6}$ show the $R_{\mathrm{a}}$ values obtained for. Figure 5 indicates that as the electrode rotation speed is increased, the $R_{\mathrm{a}}$ values decrease across all tests. This is a welcome outcome in terms of the overall industry goal

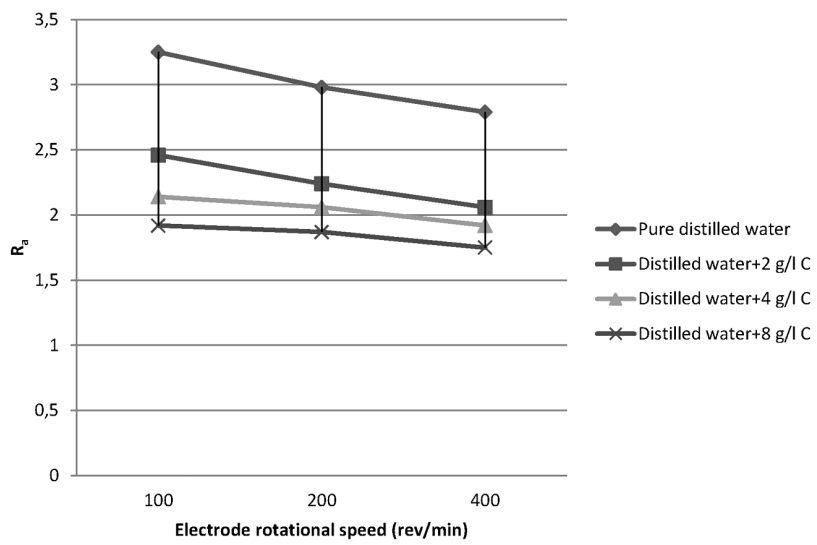

Figure 5: Electrode rotation speed vs. $R_{\mathrm{a}}$ (constant spray pressure at 20 bar)

Slika 5: Odvisnost hitrosti vrtenja elektrode od hrapavosti $R_{\mathrm{a}}$ (konstanten tlak curka 20 bar) of obtaining lower $R_{\mathrm{a}}$ values in general. A preliminary explanation offered for the decrease observed in $R_{\mathrm{a}}$ values is the easier electrode plunge action due to its rotation. Note that during testing, as the rotation speed was increased, the drilling duration was observed to decrease.

In tests conducted using the pure distilled water dielectric fluid (column Di-0) at 20 bar pressure (test group $\mathrm{A}$ ), the $R_{\mathrm{a}}$ value decreased by $8 \%$ (from $3.25 \mu \mathrm{m}$ to $2.98 \mu \mathrm{m}$ ) as the electrode rotation speed was increased from $100 \mathrm{~min}^{-1}$ to $200 \mathrm{~min}^{-1}$, the $R_{\mathrm{a}}$ value decreasing by another $6 \%$ (from $2.98 \mu \mathrm{m}$ to $2.79 \mu \mathrm{m}$ ) as electrode rotation speed increased from $200 \mathrm{~min}^{-1}$ to $400 \mathrm{~min}^{-1}$ (corresponding to surface roughness results for individual tests A-1, A-2, and A-3, under column Di-0). For tests conducted with dielectric fluid of distilled water mixed with $2 \mathrm{~g} / \mathrm{L}$ carbon powder (column Di-1) at 20 bar pressure (test group A), the decreases were $9 \%$ and $8 \%$, for rotation speed increases from $100 \mathrm{~min}^{-1}$ to $200 \mathrm{~min}^{-1}$, and from $200 \mathrm{~min}^{-1}$ to $400 \mathrm{~min}^{-1}$, respectively (corresponding to surface roughness results for individual tests A-1, A-2, and A-3, under column Di-1). For the same

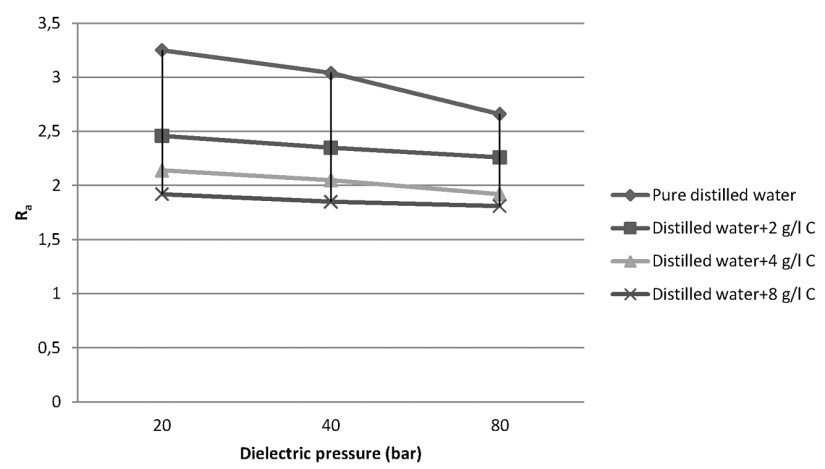

Figure 6: Dielectric pressure vs. $R_{\mathrm{a}}$ (constant rotation of $100 \mathrm{~min}^{-1}$ ) Slika 6: Odvisnost tlaka dielektrične tekočine od hrapavosti površine $R_{\text {a }}$ (pri konstanti hitrosti vrtenja $100 \mathrm{~min}^{-1}$ ) 
test group (A) conducted with dielectric fluid mixed with $4 \mathrm{~g} / \mathrm{L}$ carbon powder (column Di-2), the decreases were $4 \%$ and $7 \%$, respectively (results for individual tests A-1, A-2, and A-3, under column Di-2). For the corresponding tests conducted with dielectric fluid mixed with $8 \mathrm{~g} / \mathrm{L}$ carbon powder (column Di-3), the decreases were $3 \%$ and $6 \%$ (results for individual tests A-1, A-2, and A-3, under column Di-3).

When the same set of tests were repeated using 40 bar pressure, the observed decreases in $R_{\mathrm{a}}$ values were as follows: $7 \%$ and $4 \%$ (B-1, B-2 and B-3 under Di-0), $7 \%$ and $7 \%(\mathrm{~B}-1, \mathrm{~B}-2$ and B-3 under Di-1), $5 \%$ and $5 \%(\mathrm{~B}-1, \mathrm{~B}-2$ and B-3 under Di-2), and $2 \%$ and $10 \%$ (B-1, B-2 and B-3 under Di-3). For tests at 80 bar pressure, the observed decreases in $R_{\mathrm{a}}$ values were as follows: $2 \%$ and $4 \%$ (C-1, C-2 and C-3 under Di-0), $7 \%$ and $7 \%(\mathrm{C}-1, \mathrm{C}-2$ and $\mathrm{C}-3$ under Di- 1$), 2 \%$ and $8 \%$ (C-1, C-2 and C-3 under Di-2), and $4 \%$ and $3 \%$ (C-1, C-2 and C-3 under Di-3).

Normally, EDM processing results in craters being formed on the surface of the workpiece due to spark discharges, the presence of craters increasing the surface roughness. The decrease in surface roughness values observed here, in relation to increased rotational speeds of the electrode, is a significant outcome, as it proves that electrode rotation improves the process. The explanation for this outcome is that increased electrode rotation speeds reduce the force with which spark discharge occurs, as rotation of the electrode hinders the direct flow of spark to a single spot on the workpiece. Instead of a single spot, the spark is relayed to an area on the surface of the workpiece. As the spark is spread on the workpiece, crater depth is reduced, resulting in shallower craters. , $, 7,10,18,30$ As $R_{\mathrm{a}}$ values are directly related to the presence of craters on the workpiece, craters with less depth mean improved (lower) $R_{\mathrm{a}}$ values.

In addition to the electrode rotation speed, the study also looked at the effects of dielectric fluid spray pressure on surface roughness (Figure 6). It was observed that $R_{\mathrm{a}}$ values decreased as the dielectric fluid spray pressure was increased. For tests conducted with the electrode rotation speed kept constant at $100 \mathrm{~min}^{-1}$ and using pure distilled water dielectric fluid (individual tests A-1, B-1 and C-1 under column Di-0), increasing the spray pressure from 20 bar to 40 bar resulted in the $R_{\mathrm{a}}$ value decreasing by $6 \%$; increasing the spray pressure from 40 bar to 80 bar resulted in the $R_{\mathrm{a}}$ value decreasing by another $12 \%$. When the same tests were repeated for dielectric fluid concentration with $2 \mathrm{~g} / \mathrm{L}$ carbon, the decreases were $4 \%$ and $4 \%$ (individual tests A-1, B-1 and C-1 under column Di-1); for dielectric fluid concentration with $4 \mathrm{~g} / \mathrm{L}$ carbon, the results were $4 \%$ and $6 \%$ (same individual tests under column Di-2); and for dielectric fluid concentration with $8 \mathrm{~g} / \mathrm{L}$ carbon, the results were $4 \%$ and $2 \%$ (same individual tests under column Di-3), respectively.
The decrease in $R_{\mathrm{a}}$ values as a result of the increase in dielectric fluid spray pressure is also a significant outcome for the study. It is interpreted that as the spray pressure is increased, the spark gap is flushed clean to a greater degree, allowing debris to be removed faster. By faster flushing, a continuous supply of clean dielectric fluid is maintained. This prevents the debris buildup from contributing to unwanted spark discharges, resulting in less damage to the workpiece surface. Controlling the spark discharge is very important to obtain the desired $R_{\mathrm{a}}$ values. ${ }^{1-3,19,20,31}$ A spark gap region cluttered with debris also impedes the plunging action of the electrode, causing larger craters to be formed when the electrode's movement is obstructed; increasing the dielectric fluid spray pressure curtails this problem.

Another factor that affected $R_{\mathrm{a}}$ values was the carbon powder mixture (Figures 5 and 6). In test A-1 with dielectric fluid spray pressure of 20 bar and electrode rotation speed of $100 \mathrm{~min}^{-1}$, conducted using distilled water with carbon powder at $2 \mathrm{~g} / \mathrm{L}$ concentration (Di-1), $R_{\mathrm{a}}$ values were observed to decrease by $24 \%$ compared to the same test conducted with pure distilled water (A-1 under Di-0).For the same test conducted using distilled water with carbon powder at $4 \mathrm{~g} / \mathrm{L}$ concentration (Di-2), $R_{\mathrm{a}}$ values were observed to decrease by $34 \%$ compared to the test with pure distilled water (A-1 under Di-0). When using distilled water with carbon powder mixed in at $8 \mathrm{~g} / \mathrm{L}$ concentration (Di-3), $R_{\mathrm{a}}$ values were observed to decrease by $41 \%$ compared to the same test conducted with pure distilled water (A-1 under Di-0). In test A-2 with electrode rotation speed of $200 \mathrm{~min}^{-1}$, the observed decreases in $R_{\mathrm{a}}$ values were $25 \%, 30 \%$ and $37 \%$, respectively, for Di-1, Di-2, and Di-3, when compared to the $R_{\mathrm{a}}$ value for Di-0. In test A-3 with electrode rotation speed of $400 \mathrm{~min}^{-1}$, the observed decreases in $R_{\mathrm{a}}$ values were $26 \%, 31 \%$ and $37 \%$, respectively, for Di-1, Di-2, and Di-3, when compared to the $R_{\mathrm{a}}$ value for $\mathrm{Di}-0$.

In the case of a dielectric fluid spray pressure of 40 bar with electrode rotation at $100 \mathrm{~min}^{-1}$ (test B-1), the observed decreases in $R_{\mathrm{a}}$ values were $23 \%, 33 \%$ and $39 \%$, respectively, for $\mathrm{Di}-1, \mathrm{Di}-2$, and $\mathrm{Di}-3$, when compared to the $R_{\mathrm{a}}$ value for $\mathrm{Di}-0$. In the case of dielectric fluid spray pressure of 80 bar with electrode rotation at $100 \mathrm{~min}^{-1}$ (test C-1), the observed decreases in $R_{\mathrm{a}}$ values were $15 \%, 28 \%$ and $32 \%$, respectively, for Di-1, Di-2, and Di-3, when compared to the $R_{\mathrm{a}}$ value for $\mathrm{Di}-0$.

In all of the tests conducted, it was observed that the carbon powder had a positive effect in decreasing $R_{\mathrm{a}}$ values. The cause is interpreted to be the wider discharge gap that is possible due to the use of the carbon powder mix. A wider discharge gap allows sparks to act on a larger workpiece surface area, leading to craters with less depth, and in turn, lower $R_{\mathrm{a}}$ values. During the hole drilling operation, loose debris from the workpiece increases the spark discharge between the electrode's lateral surfaces and the workpiece. This in turn leads to high points 


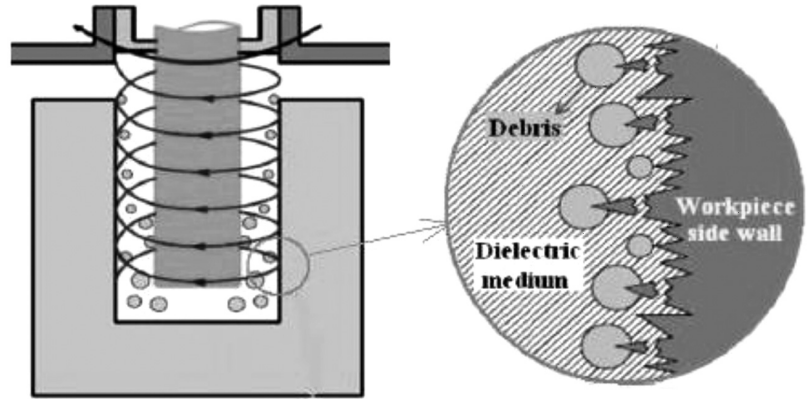

Figure 7: Debris in the spark gap region ${ }^{18}$

Slika 7: Drobci v področju reže $\mathrm{e}^{18}$

on the workpiece surface being melted and vaporized (Figure 7), enabling lower $R_{\mathrm{a}}$ values to be attained. . $^{21,26-28,32}$

An additional reason for the observed decrease in $R_{\mathrm{a}}$ values when carbon powder mixes are used is the formation of low-power sparks among the carbon particulates and the workpiece surface. These low-power sparks cause shallow craters, which improve $R_{\mathrm{a}}$ values. ${ }^{26,33}$

The answer to whether further increasing carbon powder concentrations would help boost the observed decreases in $R_{\mathrm{a}}$ values was investigated through additional testing not included in this study. In the additional tests, carbon powder concentrations of $16 \mathrm{~g} / \mathrm{L}$ and $20 \mathrm{~g} / \mathrm{L}$ were used, but did not yield further improvements. Thus this study has been limited to reporting carbon powder mixed to an $8 \mathrm{~g} / \mathrm{L}$ concentration. The interpretation for the limit reached in the efficiencies is two-fold: congestion within the electrode, and short circuits created within the spark gap. This study has demonstrated that specific carbon powder concentrations are highly effective on $R_{\mathrm{a}}$ and that an optimal carbon powder mix is an effective path to achieving low $R_{\mathrm{a}}$ values.

\subsection{Analysis of the findings relating to average radial overcut (ARO)}

The average radial overcut $(A R O)$, an important parameter in describing the results obtained from EDM hole drilling operations, is the average difference between the diameter of the hole and the diameter of the electrode. The $A R O$ value provides information on the hole profile; a lower value indicates that hole diameter is

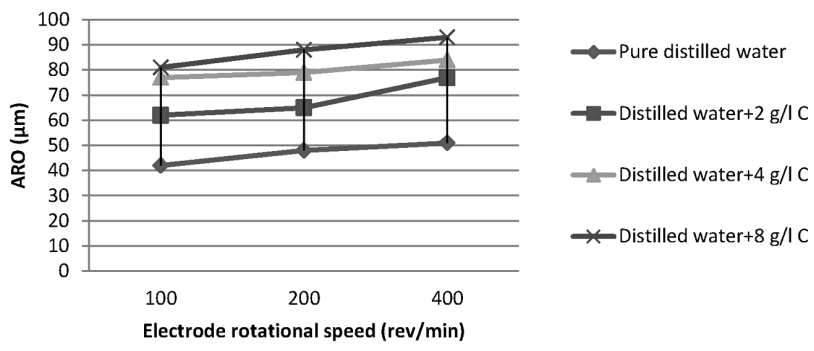

Figure 8: Electrode rotation speed vs. ARO (constant spray pressure at 20 bar)

Slika 8: Odvisnost hitrosti vrtenja elektrode od $A R O$ (pri konstantnem tlaku curka 20 bar) close to the electrode diameter. Figures $\mathbf{8}$ and $\mathbf{9}$ present the $A R O$ values attained in the study in relation to machining parameters as well as the carbon powder concentrations used.

The results presented in Figures 8 and 9 indicate that increases in electrode rotation speed, dielectric fluid spray pressure and carbon powder concentrations, increase $A R O$ values. In tests conducted using pure distilled water dielectric fluid (without carbon powder) (column Di-0) at 20 bar pressure (test group A), the ARO value increased by $14 \%$ (from $42 \mu \mathrm{m}$ to $48 \mu \mathrm{m}$ ) as electrode rotation speed was increased from $100 \mathrm{~min}^{-1}$ to $200 \mathrm{~min}^{-1}$, and the $A R O$ value increased by another $6 \%$ (from $48 \mu \mathrm{m}$ to $51 \mu \mathrm{m}$ ) as electrode rotation speed was increased from $200 \mathrm{~min}^{-1}$ to $400 \mathrm{~min}^{-1}$ (corresponding to $A R O$ results for individual tests $\mathrm{A}-1, \mathrm{~A}-2$, and A-3, under column Di-0). For tests conducted with dielectric fluid of distilled water mixed with $2 \mathrm{~g} / \mathrm{L}$ carbon powder (column Di-1) at 20 bar pressure (test group A), the increases were $5 \%$ and $18 \%$, corresponding to the rotation speed increase from $100 \mathrm{~min}^{-1}$ to $200 \mathrm{~min}^{-1}$, and from $200 \mathrm{~min}^{-1}$ to $400 \mathrm{~min}^{-1}$, respectively (corresponding to $A R O$ results for individual tests A-1, A-2, and A-3, under column Di-1). For the same test group (A) conducted with dielectric fluid mixed with $4 \mathrm{~g} / \mathrm{L}$ carbon powder (column Di-2), the increases were $3 \%$ and $6 \%$, respectively (results for individual tests A-1, A-2, and A-3, under column Di-2) and for tests conducted with $8 \mathrm{~g} / \mathrm{L}$ carbon powder (column Di-3), the increases were $9 \%$ and $6 \%$ (results for individual tests A-1, A-2, and A-3, under column Di-3), respectively. Similar increases in $A R O$ values at all electrode rotation speeds were observed for test groups B and C, corresponding to dielectric fluid spray pressures of 40 bar and 80 bar, respectively.

In addition to the electrode rotation speed, the study also looked at the effects of dielectric fluid spray pressure on $A R O$ values. It was observed that $A R O$ values increased as dielectric fluid spray pressure was increased. For tests conducted with the electrode rotation speed kept constant at $100 \mathrm{~min}^{-1}$ and using dielectric fluid of pure distilled water (individual tests A-1, B-1 and $\mathrm{C}-1$ under column Di-0), increasing the spray pressure from 20 bar to 40 bar resulted in the $A R O$ value increasing by $26 \%$; increasing the spray pressure from

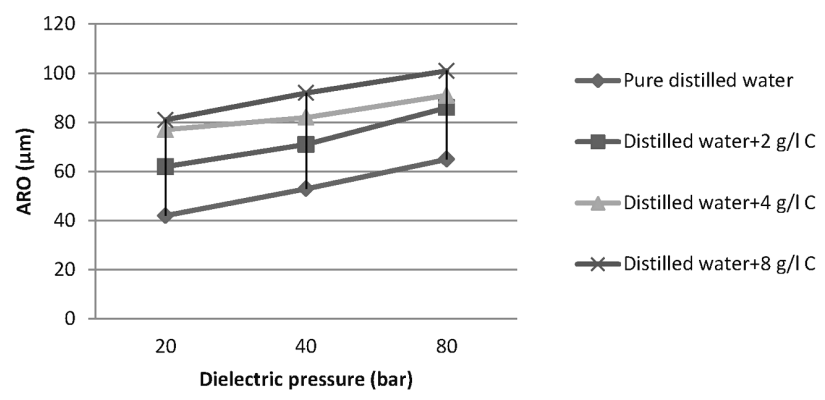

Figure 9: Dielectric pressure vs. ARO (constant rotation of $100 \mathrm{~min}^{-1}$ ) Slika 9: Odvisnost med dielektričnim tlakom in ARO (konstantna hitrost rotacije $100 \mathrm{~min}^{-1}$ ) 
40 bar to 80 bar resulted in the $A R O$ value increasing by another $23 \%$. When the same tests were repeated for dielectric fluid concentration with $2 \mathrm{~g} / \mathrm{L}$ carbon, the increases were $15 \%$ and $21 \%$ (individual tests A-1, B-1 and C-1 under column Di-1); for the dielectric fluid concentration of $4 \mathrm{~g} / \mathrm{L}$ carbon, the results were $6 \%$ and $11 \%$ (same individual tests under column Di-2); and for dielectric fluid concentration of $8 \mathrm{~g} / \mathrm{L}$ carbon, the results were $14 \%$ and $10 \%$ (same individual tests under column Di-3).

It is argued that better flushing of the machining area with increased circulation speed of the dielectric fluid and a more effective spark discharge, explain the increase in $A R O$ values as electrode rotation speed and dielectric fluid spray pressures are increased. With faster flushing of the spark gap, the molten debris is better removed from the region, which leads to uninterrupted spark discharges. ${ }^{1,2,7,16,32}$ With uninterrupted spark discharges, continuous arcing between the electrode lateral surfaces and cavity walls increases $A R O$ values (depicted in Figure 10).

In EDM operations, debris inside the cavity may impede spark discharges, leading to a nonuniform hole profile in terms of diameter; large scale craters may also be formed. ${ }^{1-3,33,34}$ In this study, fluctuations in the hole profile were prevented by the use of electrode rotation and dielectric fluid spray through the electrode itself. Through the selection of machining parameters, the creation of large depressions in the cavity were prevented; however, a certain increase in $A R O$ values could not be avoided. This phenomena is related to electrode insulation, a current research topic with recent citations in literature, which requires further development, as research has demonstrated that insulating the lateral surfaces of the electrode helps to prevent increases in the $A R O$ values.

Another factor that affected $A R O$ values was the use of the carbon powder. In the A-1 test with dielectric fluid spray pressure of 20 bar and electrode rotation speed of $100 \mathrm{~min}^{-1}$, conducted using distilled water with carbon powder at $2 \mathrm{~g} / \mathrm{L}$ concentration (A-1 under Di-1), ARO

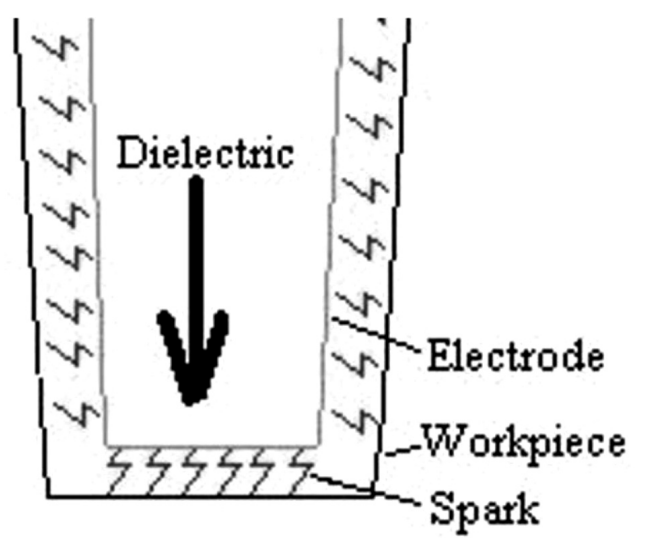

Figure 10: Increase in $A R O$ values Slika 10: Povečanje vrednosti $A R O$ values were observed to increase by $48 \%$ compared to the same test conducted with pure distilled water (A-1 under Di-0). For the same test conducted using distilled water with carbon powder at $4 \mathrm{~g} / \mathrm{L}$ concentration (A-1 under Di-2), $A R O$ values were observed to increase by $83 \%$ compared to the same test conducted with pure distilled water (A-1 under Di-0). When using distilled water with carbon powder at $8 \mathrm{~g} / \mathrm{L}$ concentration (A-1 under $\mathrm{Di}-3), A R O$ values were observed to increase by $93 \%$ compared to the same test conducted with pure distilled water (A-1 under Di-0). In test A-2 with electrode rotation speed of $200 \mathrm{~min}^{-1}$, the observed increases in $A R O$ values were $35 \%, 65 \%$ and $83 \%$, respectively, for Di-1, Di-2, and Di-3, compared to the $A R O$ value for Di-0. In test A-3 with electrode rotation speed of 400 $\mathrm{min}^{-1}$, the observed increases in $A R O$ values were $51 \%$, $65 \%$ and $82 \%$, respectively, for Di-1, Di-2, and Di-3, compared to the $R_{\mathrm{a}}$ value for Di- 0 .

In the case of dielectric fluid spray pressure of $40 \mathrm{bar}$, the observed increases in $A R O$ values were $34 \%, 55 \%$ and $74 \%$ for electrode rotation speed of $100 \mathrm{~min}^{-1}$ (test B-1), $32 \%, 46 \%$ and $66 \%$ for electrode rotation speed of $200 \mathrm{~min}^{-1}$ (test B-2), and $30 \%, 47 \%$ and $63 \%$ for electrode rotation speed of $400 \mathrm{~min}^{-1}$ (test B-3), respectively, for Di-1, Di-2, and Di-3, when compared to the $A R O$ value for $\mathrm{Di}-0$. In the case of dielectric fluid spray pressure of 80 bars, the observed increases in $A R O$ values were $32 \%, 40 \%$ and $55 \%$ for electrode rotation speed of $100 \mathrm{~min}^{-1}$ (test C-1), $22 \%, 31 \%$ and $46 \%$ for electrode rotation speed of $200 \mathrm{~min}^{-1}$ (test C-2), and $24 \%, 34 \%$ and $47 \%$ for electrode rotation speed of 400 $\mathrm{min}^{-1}$ (test C-3), respectively, for Di-1, Di-2, and Di-3, when compared to the $A R O$ value for $\mathrm{Di}-0$.

At higher dielectric fluid spray pressure, it is observed that the increase in $A R O$ values slows down as the carbon powder concentration is increased. In the study, the lowest increase observed for $A R O$ values as a result of an increase in carbon powder concentration was for the case of the spray pressure of 80 bar. Indeed, the increases of $22 \%, 31 \%$ and $46 \%$ for test C-2 are the lowest figures for the study in terms of $A R O$ increases with carbon powder concentrations. The interpretation for this surprising finding is that, as spray pressure is increased, the spark gap is flushed clean to a greater extent, allowing faster removeal of debris. ${ }^{20,26,32-34}$ With faster flushing, a continuous supply of clean dielectric fluid is provided, preventing the debris from generating unwanted spark discharges and an excessive rise in the $A R O$ values. It also results in a decreased machining duration. An increase in machining duration would have increased the hole diameter as well as the accompanying $A R O$ values.

$A R O$ values that increase in tandem with increases in carbon powder concentrations bring to the fore a fundamental problem in EDM hole drilling. Expulsion of carbon powders through the cavity as a result of dielectric flushing leads to spark generation between 
electrode lateral surfaces and cavity walls. This has caused $A R O$ values to increase in an accelerated fashion. The most significant result achieved in this study has been the low increases in $A R O$ values observed at high dielectric fluid spray pressures for increasing powder concentrations, as decreased machining duration has positively influenced the $A R O$ values. However, when the test results are considered in their entirety, it is clear that increased carbon powder concentrations in turn increase $A R O$ values. While this outcome may in fact be exploited in certain applications, it is evident that carbon powder concentrations have a significant effect on hole profiles.

\section{CONCLUSION}

Using EDM, micro-holes with diameter of $0.5 \mathrm{~mm}$ and depth of $20 \mathrm{~mm}$ were drilled into an AISI 420 steel workpiece using four dielectric fluid concentrations, three electrode rotation speeds, and three dielectric fluid spray pressure settings. Effects of the machining parameters on the $A R O$ values for hole profile and surface roughness $\left(R_{\mathrm{a}}\right)$ have been investigated. The results of the tests are presented below.

Significant reductions in $R_{\mathrm{a}}$ values were observed by mixing carbon powder with the dielectric fluid. As the carbon powder concentration was increased, $R_{\mathrm{a}}$ values decreased. In the study, $R_{\mathrm{a}}$ values were observed to decrease as electrode rotation speed was increased. As dielectric fluid spray pressure was increased, $R_{\mathrm{a}}$ values were again observed to decrease.

The study also investigated the hole profile (i.e. ARO values); as carbon powder concentrations, electrode rotation speeds and the dielectric fluid spray pressure were increased, ARO values were observed to increase. The findings were interpreted to be the result of a continuous spark discharge being enabled. It was determined that $R_{\mathrm{a}}$ and $A R O$ values may be controlled by configuring the machining parameters and using an optimal mix of carbon powder with the dielectric fluid.

\section{REFERENCES}

${ }^{1}$ V. Y1lmaz, Experimental investigation of drillability of micro holes using electro discharge machining, Ph. D. Thesis, Gazi University Graduate School of Naturel and Applied Sciences, Ankara 2013

${ }^{2}$ V. Yılmaz, M. Sarıkaya, H. Dilipak, Deep micro-hole drilling for Hadfield steel by electro-discharge machinig (EDM), Mater. Tehnol., 49 (2015) 3, 377-386, doi:10.17222/mit.2014.091

${ }^{3}$ V. Yılmaz, C. Y. Yilmaz, M. Sarıkaya, M. Özdemir, Modelling of performance output in the hole drilling process with different electrodes to X10CrAlSi24 sheet material, $3^{\text {th }}$ International Symposium On Innovative Technologies In Engineering, Valencia, Spain, 2015, 1032-1041

${ }^{4}$ T. Kivak, Optimization of surface roughness and flank wear using the Taguchi method in milling of Hadfield steel with PVD and CVD coated inserts, Measurement, 50 (2014), 19-28, doi:10.1016/ j.measurement.2013.12.017

${ }^{5}$ G. F. Benedict, Nontraditional manufacturing processes, Marcel Dekker Inc. USA 1987, 1-250
${ }^{6}$ P. C. Pandey, H. S. Shan, Modern machining processes, Tata Mc Graw-Hill Publishing Company Limited, New Delhi 1980, 84-114

${ }^{7}$ V. Yılmaz, C. Y. Y1lmaz, M. Özdemir, M. Sarıkaya, Examination of surface roughness in the hole drilling process with different electrodes, $3^{\text {th }}$ International Symposium On Innovative Technologies In Engineering, Valencia, Spain 2015, 1024-1031

${ }^{8}$ R. K. Springborn, Non-traditional machining processes, American Society of Tool and Manufacturing Engineers, USA 1967

${ }^{9}$ T. Asokan, S. S. Reddy, P. D. E. Costa, Electrical discharge drilling of titanium alloys for aerospace applications, Proceedings of $19^{\text {th }}$ AIMTDR conference, IIT Madras, Chennai 2000, 161-165

${ }^{10}$ D. T. Pham, S. S. Dimov, S. Bigot, A. Ivanov, K. Popov, MicroEDM-recent developments and research issues, Journal of Materials Processing Technology, 149 (2004) 1-3, 50-57, doi:10.1016/ j.jmatprotec.2004.02.008

${ }^{11}$ B. H. Yan, C. C. Wang, The machining characteristics of $\mathrm{Al} 2 \mathrm{O} 3 / 6061 \mathrm{Al}$ composite using rotary electro-discharge machining with a tube electrode, Journal of Materials Processing Technology, 95 (1999) 1-3, 222-231, doi:10.1016/S0924-0136(99)00322-2

${ }^{12}$ W. Yuangang, Z. Fuling, W. Jin, Wear-resist electrodes for microEDM, Chinese Journal of Aeronautics, 22 (2009) 3, 339-342, doi:10.1016/S1000-9361(08)60108-9

${ }^{13}$ E. Ferraris, V. Castiglioni, F. Ceyssens, M. Annoni, B. Lauwers, D. Reynaerts, EDM drilling of ultra-high aspect ratio micro holes with insulated tools, CIRP Annals-Manufacturing Technology, 62 (2013) 1, 191-194, doi:10.1016/j.cirp.2013.03.115

${ }^{14}$ P. Kuppan, A. Rajadurai, S. Narayanan, Influence of EDM process parameters in deep hole drilling of Inconel 718, International Journal of Advanced Manufacturing Technology, 38 (2008) 1-2, 74-84, doi:10.1007/s00170-007-1084-y

${ }^{15}$ V. Yilmaz, H. Dilipak, Method of electro discharge machining (EDM) micro hole drilling system design, IV. UTIS 2013, Kuşadası, Turkey, 2013, 151-159

${ }^{16}$ V. Yılmaz, M. Özdemir, M. Sarıkaya, C.Y. Yılmaz, H. Dilipak, Effect to hole profile of electrode selection in the micro deep holes processing drilling with electro discharge method, $2^{\text {th }}$ International Iron and Steel Symposium, Karabük, Turkey 2015, 776-780

${ }^{17}$ Z. Y. Yu, K. P. Rajurkar, H. Shen, High aspect ratio and complex shaped blind micro holes by micro EDM, Annals of the CIRP, 51 (2002) 1, 359-362, doi:10.1016/S0007-8506(07)61536-4

${ }^{18}$ E. Bamberg, S. Heamawatanachai, Orbital electrode actuation to improve efficiency of drilling micro-holes by micro-EDM, Journal of Materials Processing Technology, 209 (2009) 4, 1826-1834, doi:10.1016/j.jmatprotec.2008.04.044

${ }^{19}$ F. N. Leao, Optimisation of EDM fast hole drilling through evaluation of dielectric and electrode materials, Proceedings of COBEM 2005, $18^{\text {th }}$ International Congress of Mechanical Engineering, Ouro Preto, MG, 2005

${ }^{20}$ S. L. Chen, B. H. Yan, F. Y. Huang, Influence of kerosene and distilled water as dielectrics on the electric discharge machining characteristics of Ti-6Al-4V, Journal of Materials Processing Technology, 87 (1999) 1-3, 107-111, doi:10.1016/S0924-0136(98) 00340-9

${ }^{21}$ R. Teimouri, H. Baseri, Effects of magnetic field and rotary tool on EDM performance, Journal of Manufacturing Processes 14 (2012) 3, 316-322, doi:10.1016/j.jmapro.2012.04.002

${ }^{22}$ J. H. Jung, W. T. Kwon, Optimization of EDM process for multiple performance characteristics using Taguchi method and Grey relational analysis, Journal of Mechanical Science and Technology, 24 (2010) 5, 1083-1090, doi:10.1007/s12206-010-0305-8

${ }^{23}$ T. Endo, T. Tsujimoto, K. Mitsui, Study of vibration-assisted microEDM-The effect of vibration on machining time and stability of discharge, Precision Engineering, 32 (2008) 4, 269-277, doi:10.1016/j.precisioneng.2007.09.003

${ }^{24}$ H. S. Liu, B. H. Yan, C. L. Chen, F. Y. Huang, Application of micro-EDM combined with high-frequency dither grinding to improve micro-hole machining, International Journal of Machine Tools \& Manufacture, 46 (2006) 1, 80-87, doi:10.1016/j.ijmachtools. 2005.03.017 
${ }^{25}$ L. Li, C. Diver, J. Atkinson, R. Giedl-Wagner, H. J. Helml, Sequential laser and EDM micro-drilling for next generation fuel injection nozzle manufacture, Annals of the CIRP 55 (2006) 1, 179-182, doi:10.1016/S0007-8506(07)60393-X

${ }^{26}$ Y. F. Tzeng, C. Y. Lee, Effects of powder characteristics on electrodischarge machining effiency, The International Journal of Advanced Manufacturing Technology, 17 (2001) 8, 586-592, doi:10.1007/ s001700170142

${ }^{27}$ Y. S. Wong, L. C. Lim, I. Rahuman, W. M. Tee, Near-mirror-finish phenomenon in EDM using powder-mixed dielectric, Journal of Materials Processing Technology, 79 (1998) 1-3, 30-40, doi:10.1016/ S0924-0136(97)00450-0

${ }^{28} \mathrm{~S}$. Singh, A. Bhardwaj, Review to EDM by using water and powdermixed dielectric fluid, Journal of Minerals \& Materials Characterization \& Engineering, 10 (2011) 2, 199-230, doi:10.4236/jmmce. 2011.102014

${ }^{29}$ H. M. Chow, L. D. Yang, C. T. Lin, Y. F. Chen, The use of SiC powder in water as dielectric for micro-slit EDM machining, Journal of Materials Processing Technology, 195 (2008) 1-3, 160-170, doi:10.1016/j.jmatprotec.2007.04.130

${ }^{30}$ T. Muthuramalingam, B. Mohan, A review on influence of electrical process parameters in EDM process, Archives of Civil and Mechanical Engineering, 15 (2015) 1, 87-94, doi:10.1016/j.acme. 2014.02.009
${ }^{31}$ V. Yılmaz, H. Dilipak, M. Özdemir, G. Uzun, Examining the surface roughness while drilling micro-size deep holes with electro discharge technique on Hadfield steel, $2^{\text {th }}$ International Symposium On Innovative Technologies In Engineering, Karabük, Turkey, 2014, 156-164

${ }^{32}$ X. Bai, Q. Zhang, J. Zhang, D. Kong, T. Yang, Machining efficiency of powder mixed near dry electrical discharge machining based on different material combinations of tool electrode and workpiece electrode, Journal of Manufacturing Processes, 15 (2013) 4, 474-482, doi:10.1016/j.jmapro.2013.09.005

${ }^{33}$ P. Huabei, Y. Deping, Z. Xun, W. Shanling, W. Yuhua, Fabrication of hollow nickel micro-spheres with high degree of hollowness by silicon powder-mixed spark erosion, International Journal of Machine Tools \& Manufacture 85 (2014), 131-134, doi:10.1016/ j.ijmachtools.2014.06.002

${ }^{34}$ M. P. Jahan, M. Rahman, Y. S. Wong, A review on the conventional and micro-electro discharge machining of tungsten carbide, International Journal of Machine Tools \& Manufacture, 51 (2011) 12, 837-858, doi:10.1016/j.ijmachtools.2011.08.016 